\title{
A review of the utility of a hypothermia protocol in cardiac arrests due to non-shockable rhythms
}

\author{
Brin Freund ${ }^{1}$, Peter W. Kaplan ${ }^{2}$ \\ ${ }^{1}$ Department of Neurology, Johns Hopkins Hospital, Baltimore, MD, United States \\ ${ }^{2}$ Department of Neurology, Johns Hopkins Bayview Medical Center, Baltimore, MD, United States
}

\begin{abstract}
Background: Therapeutic hypothermia and targeted temperature management are considered standard of care in the management of patients following out-of-hospital cardiac arrests due to shockable rhythms to improve neurological outcomes. In those presenting out-of-hospital cardiac arrests associated with non-shockable rhythms, the benefit of hypothermia is less clear. In this review we try to clarify the utility of implementing a hypothermia protocol after cardiac arrests due to non-shockable rhythms. Methods: PUBMED, Ovid, MEDLINE, EMBASE, and clinicaltrials.gov websites were searched through during October, 2016 using the terms "non shockable", "hypothermia," and "cardiac arrest." Studies were excluded if they solely evaluated in-hospital cardiac arrests, shockable rhythms, and/or pediatric patients. Data was extracted by two authors.

Results: Forty studies were included in this review, most of which were not randomized or controlled, nor were they powered to make significant conclusions about the efficacy of hypothermia in this population. Some did evaluate specific factors that may portend to a better outcome in patients presenting with out-of-hospital cardiac arrest due to non-shockable rhythms undergoing hypothermia. Shortcomings included incorporating in-hospital cardiac arrest patients in analyses, comparing results of hypothermia in shockable versus non-shockable rhythm patients as an outcome measure, lacking standardization in cooling protocols, and short-term measures of outcomes.

Conclusions: It was concluded that further study is needed to characterize patients presenting nonshockable rhythms who would benefit from hypothermia to better guide its use in this population given the costs and implications of treatment and long-term care in those who survive with poor outcomes. (Cardiol J 2017; 24, 3: 324-333)
\end{abstract}

Key words: cardiac arrest, non shockable, hypothermia, targeted temperature management

\section{Introduction}

With roughly 400,000 out-of-hospital cardiac arrests (OHCA) in the United States per year [1], therapeutic hypothermia (TH) or targeted temperature management (TTM) is now the standard of care in their management. The pathophysiology underlying the effect of body temperature on hypoxic-ischemic brain injury has been described in detail [2-4]. Improved outcomes have been demonstrated in randomized controlled trials (RCTs) in a group of post-anoxic patients who present with
OHCA due to "shockable rhythms," ventricular fibrillation (VF) or pulseless ventricular tachycardia (VT) [2-4].

It has been well established that more patients are presenting with cardiac arrest (CA) due to non-shockable rhythms (nSR), pulseless electrical activity (PEA) or asystole, than VT/VF [5]. This is possibly related to more aggressive cardiac interventions and better long-term medical management of coronary disease and heart failure. This may ultimately lead to fewer OHCA due to

Address for correspondence: Brin Freund, MD, Department of Neurology, Johns Hopkins Hospital, 600 N. Wolfe St., Zayed Tower, Room 6005, Baltimore, MD 21287, United States, e-mail: bfreund3@jhmi.edu 


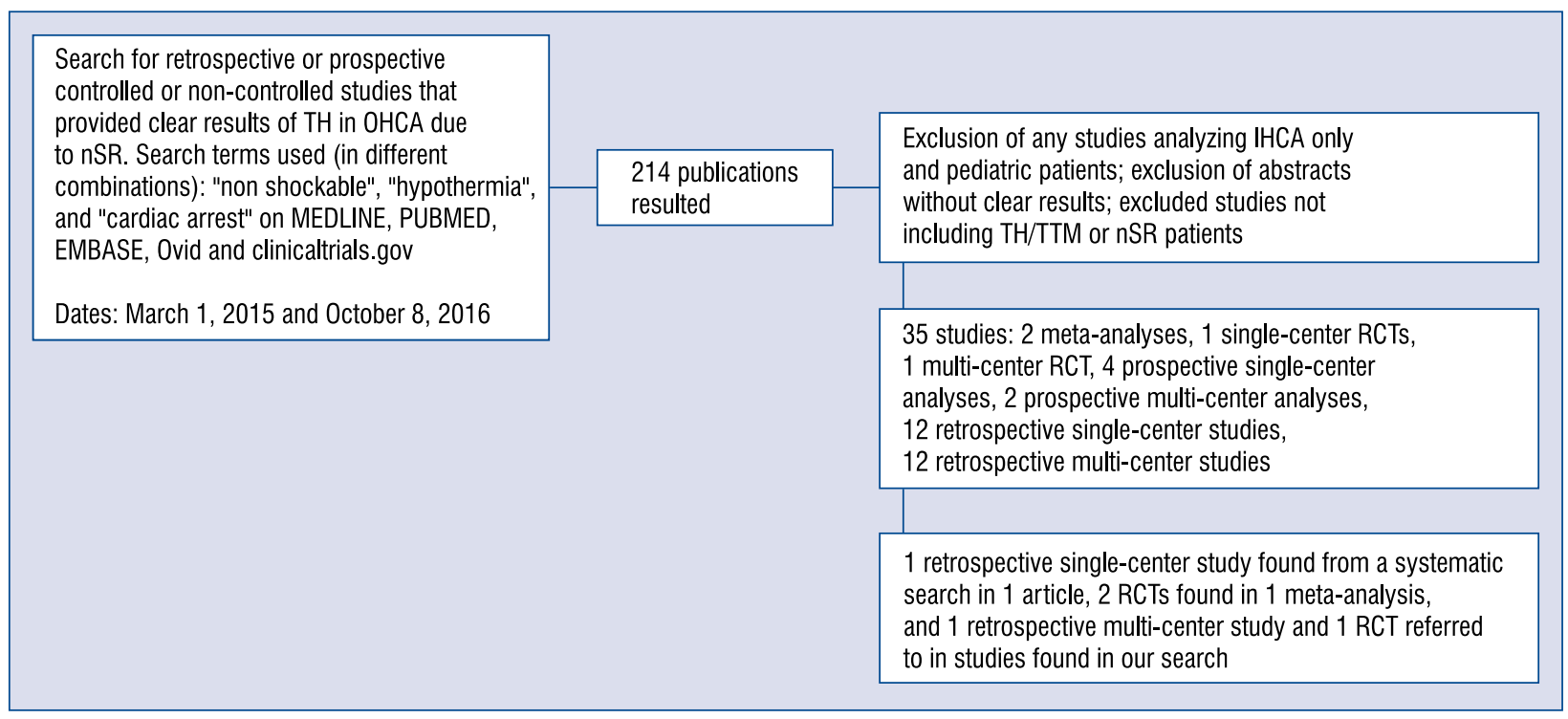

Figure 1. Literature search for studies evaluating therapeutic hypothermia $(\mathrm{TH}) /$ targeted temperature management (TTM) in out-of-hospital cardiac arrests (OHCA) due to non-shockable rhythm (nSR); IHCA — in-hospital cardiac arrests; RCT — randomized controlled trial.

VT/VF $[5,6]$. Yet a fewer percentage of patients presenting with OHCA due to nSR receive $\mathrm{TH} /$ /TTM than those with VT/VF [5]. The largest RCTs on TH/TTM in OHCA have excluded nSR $[2,3]$ or were not designed to evaluate the effects of hypothermia in nSR as a primary outcome [4]. This is likely because studies have revealed significantly worse outcomes in OHCA associated with $\mathrm{nSR}$, and intervention has been assumed to have little benefit given the costs [7, 8]. However, a hypothermia protocol may be beneficial in a subgroup of patients presenting with OHCA due to nSR if certain criteria are met [8]. Though recent publications support the use of TH/TTM in cardiac arrests regardless of rhythm [9, 10], understanding the clinical variables that render patients suitable candidates for TH/TTM, especially in those presenting with $\mathrm{nSR}$, is vital given that cost-benefit is a reason proposed by some institutions to withhold treatment, especially when considering the consequences of long-term care in survivors with poor outcomes.

In this article, a review the literature on $\mathrm{TH} /$ TTM in OHCA due to nSR is presented. We point out possible clinical features that may make certain patients presenting with OHCA due to nSR good candidates for intervention and discuss the difficulties in extrapolating the results of these studies to refute or support the benefit of TH/TTM in OHCA due to nSR.

\section{Methods}

A systematic literature search was performed using PUBMED, Ovid, MEDLINE, EMBASE, and clinicaltrials.gov websites first in March, 2015 and then again in October, 2016. The primary author (BF) performed the search. Both authors (BF, PK) decided which studies would be included or excluded. The terms "non shockable," "hypothermia," and "cardiac arrest" in different combinations were used. Studies included those which demonstrated outcomes from TH in OHCA due to nSR. Studies were excluded if it was clearly stated that they included only those with shockable rhythms, in-hospital cardiac arrests (IHCA) or pediatric patients. Many of the results were abstracts submitted to meetings and if results were unclear with respect to the efficacy of TH/TTM in nSR they were also excluded (Fig. 1).

Each study was evaluated by the quality of its data using a categorical system adapted from a previously published guideline by American Academy of Neurology (AAN) [10] which was modified by Dr. David Gloss. The quality of each study was based on a categorical rating as follows: Category I - broad spectrum prospective trial; Category II - narrow spectrum, prospective trial or broad spectrum retrospective trial; Category III — narrow spectrum, retrospective trial or case control study; Category IV - review, case series, expert opinion paper (Table 1). 
Table 1. Studies evaluating therapeutic hypothermia (TH)/targeted temperature management (TTM) in out-of-hospital cardiac arrests due to non-shockable rhythm.

\begin{tabular}{|c|c|c|c|}
\hline Study & Study type & Survival/outcome with TH/TTM & Data quality \\
\hline \multicolumn{4}{|c|}{ Studies demonstrating benefit from TH/TTM } \\
\hline Choi [11] & $\begin{array}{l}\text { Retrospective } \\
\text { multicenter } \\
\text { study }\end{array}$ & $\begin{array}{c}\text { OR for survival to discharge: PEA }=2.28(95 \% \mathrm{Cl} 1.69-3.07) \text {, } \\
\text { Asystole }=1.84(95 \% \mathrm{Cl} 1.58-2.15) ; \text { ORs for good } \\
\text { outcome (CPC 1-2): PEA }=2.3(95 \% \mathrm{Cl} 1.50-3.53) \\
\text { Asystole }=1.07(\mathrm{Cl} 0.83-1.38)\end{array}$ & Category II data \\
\hline Lindner [12] & $\begin{array}{l}\text { Prospective } \\
\text { multicenter study }\end{array}$ & $\begin{array}{c}17 \% \text { survived to discharge }(p=0.051) ; 14 \% \text { TH vs. } 9 \% \\
\text { of controls }(p=0.094) \text { had good outcome }\end{array}$ & Category III data \\
\hline Sung [13] & $\begin{array}{l}\text { Retrospective } \\
\text { multicenter study }\end{array}$ & $\begin{array}{l}\text { For all nSR }- \text { OR for good outcome } \\
\quad(\text { CPC } 1-2)=2.9(95 \% \text { Cl } 1.9-4.4)\end{array}$ & Category III data \\
\hline Testori [14] & $\begin{array}{l}\text { Retrospective } \\
\text { single center } \\
\text { analysis }\end{array}$ & $\begin{array}{l}\text { Improved survival at } 6 \text { months with TH with adjusted } \\
\text { OR } 0.56(95 \% \mathrm{Cl} 0.34-0.93), \mathrm{p}=0.025 ; 35 \% \text { of TH-treated } \\
\text { patients had good outcomes (CPC 1-2) adjusted OR } 1.84 \\
(95 \% \mathrm{Cl} 1.08-3.13), \mathrm{p}=0.024\end{array}$ & Category III data \\
\hline Lundbye [15] & $\begin{array}{l}\text { Retrospective } \\
\text { single center } \\
\text { analysis }\end{array}$ & $\begin{array}{c}\text { Adjusted OR for survival to discharge was } 5.65(95 \% \mathrm{Cl} \\
1.66-19.23), \mathrm{p}=0.06 \text { in TH group; adjusted OR for good } \\
\text { neurologic outcome from TH was } 4.35 \\
(95 \% \mathrm{Cl} 1.10-17.24), \mathrm{p}=0.04\end{array}$ & Category III data \\
\hline Soga [16] & $\begin{array}{l}\text { Retrospective } \\
\text { multicenter } \\
\text { study }\end{array}$ & $\begin{array}{l}59 \% \text { of patients survived to } 30 \text { days with } \mathrm{TH} ; 32 \% \text { of those } \\
\text { undergoing TH had a favorable outcome; if ROSC } \\
<16 \text { min, outcomes were similar to VT/VF }(p=0.84)\end{array}$ & Category III data \\
\hline $\operatorname{Kim}(17)$ & $\begin{array}{c}\text { Meta-analysis and } \\
\text { systematic review } \\
\text { including } 2 \text { RCTs, } \\
6 \text { prospective } \\
\text { ( } 2 \text { multicenter) } \\
\text { and } 6 \text { retrospec- } \\
\text { tive analyses } \\
\text { (4 included IHCA } \\
\text { and OHCA) }\end{array}$ & $\begin{array}{c}\text { Decreased in-hospital mortality (OR } 0.84,95 \% \mathrm{Cl} \\
0.78-0.92 \text { ) in the non-randomized studies in } \\
\text { TH groups; pooled RR for } 6 \text { month mortality } 0.85 \\
\text { (95\% } \mathrm{Cl} 0.65-1.11 \text { ) in the } 2 \text { RCTs in those } \\
\text { undergoing TH; trend towards less poor outcomes } \\
\text { in those undergoing TH (OR } 0.95,95 \% \mathrm{Cl} 0.90-1.01 \text { ) } \\
\text { in the non-randomized studies }\end{array}$ & Category IV data \\
\hline Kim [19] & $\begin{array}{l}\text { Retrospective } \\
\text { multicenter } \\
\text { study }\end{array}$ & $\begin{array}{c}\text { Unadjusted OR } 2.34(95 \% \mathrm{Cl} 1.08-5.05) \text { for women and } \\
\text { unadjusted OR } 1.67(95 \% \mathrm{Cl} 1.01-2.75) \text { for men with } \\
\text { good outcome (CPC 1-2) (under } 45 \text { years old); } \\
\text { Unadjusted OR } 1.53(95 \% \mathrm{Cl} 1.09-2.14) \text { for men } \\
\text { with CPC } 1-2(45-65 \text { years old) }\end{array}$ & Category II data \\
\hline Yoshida [39] & $\begin{array}{l}\text { Retrospective } \\
\text { single center } \\
\text { analysis }\end{array}$ & $\begin{array}{l}\text { Significantly more patients with CPC } 1-2 \text { ( } p<0.0001 \\
\text { at } 3 \text { months) and better survival ( } p<0.0001 \text { at } 3 \text { months) } \\
\text { if pulmonary embolism was cause of OHCA; incidental } \\
\text { hypothermia increased likelihood of } 3-\text { month survival } \\
(p<0.0001) \text { and good outcome }(p<0.0001)\end{array}$ & Category II data \\
\hline Fontanals [40] & $\begin{array}{l}\text { Retrospective } \\
\text { single center } \\
\text { analysis }\end{array}$ & $\begin{array}{l}\text { Survival at } 12 \text { months }-33.3 \% \\
\text { and CPC } 1-2-25 \%\end{array}$ & Category III data \\
\hline Katz [41] & $\begin{array}{l}\text { Retrospective } \\
\text { multicenter } \\
\text { study }\end{array}$ & $\begin{array}{l}\text { No difference in outcomes or survival in patients who } \\
\text { overdosed vs. non-overdose patients undergoing } \\
\text { TTM despite more nSR in the overdose group }\end{array}$ & Category III data \\
\hline Lee [42] & $\begin{array}{l}\text { Retrospective } \\
\text { multicenter } \\
\text { study }\end{array}$ & $\begin{array}{c}\text { Adjusted OR } 2.05(95 \% \mathrm{Cl} 1.51-2.79) \text { for survival to } \\
\text { discharge in nSR undergoing TH vs. control and OR } 1.13 \\
(95 \% \mathrm{Cl} 0.59-2.20) \text { for good neurologic outcome } \\
\text { in nSR undergoing TH vs. control }\end{array}$ & Category II data \\
\hline Nair [43] & $\begin{array}{l}\text { Prospective } \\
\text { single center } \\
\text { study }\end{array}$ & $\begin{array}{c}\text { Of the } 64 \text { post-cardiac arrest patients in the hypothermia } \\
\text { group, } 16(25 \%) \text { had a CPC } 1-2 \text { (good outcome) which } \\
\text { was associated with time down and time to CPR }\end{array}$ & Category II data \\
\hline Perman [47] & $\begin{array}{l}\text { Retrospective } \\
\text { multicenter } \\
\text { study }\end{array}$ & $\begin{array}{c}\text { OR } 3.1(95 \% \mathrm{Cl} 1.6-5.8) \text { for survival to discharge in those } \\
\text { undergoing } \mathrm{TH} \text { in the nSR group; OR } 2.1(95 \% \mathrm{Cl} 1.0-4.4) \\
\text { for good outcomes in } \mathrm{TH} \text { in nSR group }\end{array}$ & Category III data \\
\hline
\end{tabular}


Table 1 (cont.). Studies evaluating therapeutic hypothermia(TH)/targeted temperature management (TTM) in out-of-hospital cardiac arrests due to non-shockable rhythm.

\begin{tabular}{|c|c|c|c|}
\hline Study & Study type & Survival/outcome with TH/TTM & Data quality \\
\hline \multicolumn{4}{|c|}{ Studies demonstrating no benefit from TH/TTM } \\
\hline Vaahersalo [5] & $\begin{array}{l}\text { Prospective } \\
\text { multicenter study }\end{array}$ & $\begin{array}{l}80.6 \% \text { of those with nSR undergoing TH survived } \\
\text { with CPC } 3-5(p=0.56)\end{array}$ & Category II data \\
\hline Martinell [6] & $\begin{array}{l}\text { Prospective } \\
\text { single center } \\
\text { study }\end{array}$ & $\begin{array}{c}\text { OR } 0.67 \text { (95\% } \mathrm{Cl} 0.31-1.46) \text { for survival at } 30 \text { days in group } \\
\text { undergoing } \mathrm{TH} \text { and } \mathrm{OR} 0.64(95 \% \mathrm{Cl} 0.27-1.54) \text { for survival } \\
\text { at } 1 \text { year in this group despite significant increase in use } \\
\text { of } \mathrm{TH} \text {; CPC score among survivors was not significantly } \\
\text { different if undergoing } \mathrm{TH}(\mathrm{p}=0.36)\end{array}$ & Category II data \\
\hline Frydland [18] & $\begin{array}{l}\text { Multicenter RCT } \\
\text { (sub-group } \\
\text { analysis) }\end{array}$ & $\begin{array}{c}\text { Mortality } 84 \% \text { in TTM } 33 \text { and TTM } 36 ; 13 \% \text { had } \\
\text { a good outcome in the TTM33 group and } \\
15 \% \text { in the TTM36 group }\end{array}$ & Category II data \\
\hline $\begin{array}{l}\text { Lopez-de-sa } \\
\text { [20] }\end{array}$ & Single center RCT & No survivors at 6 months (asystole only) & Category II data \\
\hline Dumas [21] & $\begin{array}{l}\text { Prospective single } \\
\text { center study }\end{array}$ & $\begin{array}{l}16 \% \text { overall survival in the TH group with a trend } \\
\text { toward better outcomes versus controls } \\
\text { (OR } 0.71,95 \% \mathrm{Cl} 0.37-1.36 \text { ), } \mathrm{p}=0.48\end{array}$ & Category II data \\
\hline Storm [22] & $\begin{array}{l}\text { Prospective single } \\
\text { center study }\end{array}$ & $27.59 \%$ good outcome in TH group $(p=0.175)$ & Category III data \\
\hline Wee [23] & $\begin{array}{l}\text { Retrospective } \\
\text { multicenter } \\
\text { study }\end{array}$ & $\begin{array}{c}46 / 80 \text { patients survived in the TH group; } 6 / 80 \text { patients } \\
\text { had good outcome; no association of rhythm with } \\
\text { survival ( } p=0.737)\end{array}$ & Category III data \\
\hline Hoffmann [24] & $\begin{array}{l}\text { Retrospective } \\
\text { single center } \\
\text { analysis }\end{array}$ & $\begin{array}{c}\text { None of the OHCA and nSR undergoing hypothermia } \\
\text { had favorable outcome }\end{array}$ & Category III data \\
\hline Uribarri [25] & $\begin{array}{l}\text { Retrospective } \\
\text { single center } \\
\text { analysis }\end{array}$ & $\begin{array}{c}3 / 44 \text { in } \mathrm{nSR} \text { group survived with } \mathrm{CPC} \leq 2, \text { adjusted } \\
\text { OR } 13.8(95 \% \mathrm{Cl}=3.4-56.1), \mathrm{p}<0.001 \text { compared } \\
\text { to all undergoing } \mathrm{TH}\end{array}$ & Category III data \\
\hline Kocjanic $[26]$ & $\begin{array}{l}\text { Retrospective } \\
\text { single center } \\
\text { analysis }\end{array}$ & $\begin{array}{l}9 \% \text { survived with CPC } 1-2 \text { with TH } \\
\text { ("intensified resuscitation") ( } p=0.27)\end{array}$ & Category III data \\
\hline Ganga [27] & $\begin{array}{l}\text { Retrospective } \\
\text { single center } \\
\text { analysis }\end{array}$ & $17 / 98$ with nSR reached CPC 1-2 & Category III data \\
\hline Gebhardt [28] & $\begin{array}{l}\text { Retrospective } \\
\text { single center } \\
\text { analysis }\end{array}$ & $\begin{array}{c}\text { In TH cohort presence of PEA predicted poor outcome } \\
\text { (OR } 0.09,95 \% \mathrm{Cl} 0.02-0.40 \text { for good outcome, defined } \\
\text { as disposition home/rehab) }\end{array}$ & Category III data \\
\hline Schenone [29] & $\begin{array}{l}\text { Meta-analysis } \\
\text { and systematic } \\
\text { review including } \\
3 \text { RCTs, } 8 \text { cohort } \\
\text { studies evaluating } \\
\text { shockable and } \\
\text { non-shockable } \\
\text { rhythms (1 RCT } \\
\text { and } 6 \text { cohort } \\
\text { studies included } \\
\text { nSR) }\end{array}$ & $\begin{array}{l}\text { Did not specifically evaluate effects of TH on nSR } \\
\text { separately from a group of pooled results of nSR } \\
\text { and VT/VF, did evaluate levels of temperature in nSR } \\
\text { and found non-significant benefit of } \\
\text { lower temperature vs. higher temperature } \\
\text { in good outcome (CPC 1-2) in nSR }\end{array}$ & Category IV data \\
\hline Modisett [30] & $\begin{array}{l}\text { Retrospective } \\
\text { single center } \\
\text { analysis }\end{array}$ & $\begin{array}{c}\text { 11/18 patients with VT/VF and 7/30 patients with } \\
\text { nSR survived }(p=0.01)\end{array}$ & Category III data \\
\hline Whittaker [31] & $\begin{array}{l}\text { Retrospective } \\
\text { single center } \\
\text { analysis }\end{array}$ & $\begin{array}{c}\text { OR for death } 5.6(95 \% \mathrm{Cl} 2.0-15.4), \mathrm{p}=0.018 \\
\text { when compared nSR to VT/VF, only } 3 \text { patients } \\
\text { with nSR survived to discharge }\end{array}$ & Category III data \\
\hline
\end{tabular}


Table 1 (cont.). Studies evaluating therapeutic hypothermia(TH)/targeted temperature management (TTM) in out-of-hospital cardiac arrests due to non-shockable rhythm.

\begin{tabular}{|c|c|c|c|}
\hline Study & Study type & Survival/outcome with TH/TTM & Data quality \\
\hline Kim [32] & $\begin{array}{l}\text { Retrospective } \\
\text { multicenter study }\end{array}$ & $\begin{array}{l}\text { More patients with nSR than VT/VF in the bad outcome } \\
\text { group (CPC } 3-5) \text { and more VT/VF than nSR patients and } \\
\text { in the good outcome group (CPC 1-2) ( } p<0.01)- \text { likely } \\
\text { skewed by asystole; multivariate analysis for decreased } \\
\text { chance of good outcome in nSR with OR } 7.13 \\
(95 \% \text { Cl } 4.85-10.48)\end{array}$ & Category II data \\
\hline Afzal [33] & $\begin{array}{l}\text { Retrospective } \\
\text { single center } \\
\text { study }\end{array}$ & $\begin{array}{c}\text { Of those receiving TH: in the VT/VF group - } 69 \% \text { expired, } \\
23 \% \text { went home, and } 7.7 \% \text { were sent to nursing facility; } \\
\text { in the nSR group }-89.7 \% \text { expired, } 7.6 \% \text { went home } \\
\text { and } 2.5 \% \text { went to nursing facility }\end{array}$ & Category III data \\
\hline Thomsen [34] & $\begin{array}{l}\text { Retrospective } \\
\text { single center } \\
\text { study }\end{array}$ & $\begin{array}{c}\text { nSR was a significant predictor of mortality } \mathrm{HR}=2.26 \\
(95 \% \mathrm{Cl} 1.67-3.07) \text {, and having any comorbidity noted in } \\
\text { this study was an independent predictor of mortality in } \\
\text { nSR HR }=1.67(95 \% \mathrm{Cl} 1.08-2.59)\end{array}$ & Category III data \\
\hline Lazerri [35] & $\begin{array}{l}\text { Retrospective } \\
\text { multicenter } \\
\text { study }\end{array}$ & $\begin{array}{l}\text { More nSR observed in non-survivors }(p=0.026) \text { who } \\
\text { showed a longer collapse }- \text { recovery of spontaneous } \\
\text { circulation time }(p=0.01) \text {. Only } 3 / 18 \text { survivors } \\
\text { had presented with nSR, } 15 / 18 \text { had VT/VF }\end{array}$ & Category III data \\
\hline Kim [36] & $\begin{array}{l}\text { Retrospective } \\
\text { multicenter } \\
\text { study }\end{array}$ & $\begin{array}{l}\text { Outcomes in } n S R \text { associated with time down: } 10.3 \% \\
\text { of } n S R \text { survived with good outcome }(3 / 29) \text { if downtime } \\
>10 \text { min but } 61.5 \% \text { if downtime }<10 \text { min }\end{array}$ & Category II data \\
\hline Dell'anna [37] & $\begin{array}{l}\text { Retrospective } \\
\text { multicenter } \\
\text { study }\end{array}$ & $\begin{array}{l}75 \% \text { of non-survivors had nSR vs. } 33 \% \text { of survivors } \\
(p>0.0001) \text {; less nSR patients were in the group with } \\
\text { CPC } 1-2 \text { than in the group with CPC } 3-5 \text { ( } p<0.0001)\end{array}$ & Category III data \\
\hline Coute [38] & $\begin{array}{l}\text { Retrospective } \\
\text { multicenter } \\
\text { study }\end{array}$ & $\begin{array}{l}10.6 \% \text { (261 patients) of the total cohort received } \mathrm{TH} ; \\
\text { mortality } 83.9 \% \text { in those receiving } \mathrm{TH} \text { and } 78.5 \% \text { in } \\
\text { nSR patients in the non-TH group }(78.5 \%)(\mathrm{p}=0.04) \text {, } \\
\text { though differences by rhythm category were observed; } \\
\text { those that converted to shockable rhythm } \\
\text { had better outcomes }\end{array}$ & Category III data \\
\hline Pfeifer [44] & $\begin{array}{l}\text { Retrospective } \\
\text { single center } \\
\text { analysis }\end{array}$ & $\begin{array}{c}\text { Significantly more patients with CPC } 1-2 \text { undergoing } \\
\text { TH had VT/VF than those with CPC } 3-5 \text {; no benefit } \\
\text { in mortality from TH in nSR }(p=0.149)\end{array}$ & Category III data \\
\hline $\begin{array}{l}\text { Idriss-Hachimi } \\
\text { [45] }\end{array}$ & $\begin{array}{c}\text { Single center } \\
\text { RCT }\end{array}$ & $\begin{array}{l}15 \text { died in control group, } 12 \text { died in TH group } \\
\text { (no statistical analysis); } 2 / 16 \text { in the TH group had } \\
\text { CPC } 1-2,0 / 16 \text { had CPC } 1-2 \text { in control }\end{array}$ & Category II data \\
\hline Laurent [46] & $\begin{array}{l}\text { Two center } \\
\text { RCT }\end{array}$ & $\begin{array}{c}\text { mortality } 68 \% \text { vs. } 79 \% \text { in } \mathrm{TH} \text { and control; } \\
\text { CPC } 1-245 \% \text { in } \mathrm{TH} \text { and } 26 \% \text { in control }\end{array}$ & Category II data \\
\hline Kim [48] & $\begin{array}{l}\text { Single center } \\
\text { RCT }\end{array}$ & $\begin{array}{l}\text { In "non-VF" cohort } 9 \% \text { of field-cooled } \\
\text { patients survived }(p=0.13)\end{array}$ & Category II data \\
\hline
\end{tabular}

$\mathrm{Cl}$ - confidence interval; $\mathrm{CPC}$ - cerebral performance category; CPR - cardiopulmonary rescucitation; HR - hazard ratio; IHCA - in-hospital cardiac arrest; nSR - non-shockable rhythm; OR — odds ratios; OHCA — out-of-hospital cardiac arrests; PEA — pulseless electrical activity; $\mathrm{RCT}$ - randomized controlled trial; ROSC — return of spontaneous circulation; RR - risk ratio; TH - therapeutic hypothermia; TTM — targeted temperature management; VT/VF — ventricular tachycardia/ventricular fibrillation

\section{Results}

A total of 214 publications were gathered from our search, 35 of which were included in this analysis [5, 6, 11-43]. In 1 study [18], a literature search was performed which found 12 studies, of which 1 retrospective study [44] was not found in our search or in any of the meta-analyses. This study was added to our analysis. One of the studies above was a high quality review and meta-analysis of nSR and TH [17] which included 2 RCTs [45] and
[46] that was analyzed separately, also a non-RCT [22] was found in the search. Another more recent meta-analysis [29] included 11 trials of patients undergoing TH versus a control group which included both shockable and non-shockable rhythms. Most of the trials in their analysis had already been found in this search or were included in the previous meta-analysis that had been reviewed above [17]. Three other studies noted in this meta-analysis pooled results from TH in OHCA due to nSR and VT/VF together, so specific outcomes in nSR were 
not clarified and were thus excluded. After reviewing reference lists of the resulting papers above, 2 more studies not listed in prior searches [47] and [48] were discovered. 1 randomized, controlled trial currently enrolling [49] was also discovered, which focuses on hypothermia protocol in OHCA due to nSR. In total, 40 studies were included in the present analysis.

The studies are described in Table 1 . The results of each study are highlighted based on survival and good outcomes. Some of the studies used cerebral performance category (CPC) scale to define good outcomes while others used post-discharge disposition. There were 14 studies that demonstrated benefit with TH/TTM [11-17, 19, 47, 39-43] while 26 studies showed unclear or no benefit from TH/TTM [5, 6, 18, 20-38, 44-46, 48]. Based on a categorical system rating the quality of data, none of the studies received a Category I rating.

\section{Outcome variables}

Some of the retrospective studies noted variables that may have negatively impacted outcomes in OHCA. These include delayed time to initiating cardiopulmonary resuscitation (CPR), less bystander CPR, poor CPR quality, longer time to return of spontaneous circulation (ROSC), non-cardiac cause for arrest, medical comorbidities, older age, female gender, higher Acute Physiology and Chronic Health Evaluation (APACHE) II scores, lactic acidosis on admission, and post-resuscitation circulatory shock $[7,12,16,19-21,25,28,35,36$, $43,45]$. Some studies cited comparisons between $\mathrm{nSR}$ and VT/VF with respect to the efficacy of TH/ /TTM as major findings [7, 16, 18, 20, 24-28, 30-33, $35,44]$. One trial concluded that if ROSC was $<16$ min, TH benefitted OHCA due to nSR similarly to $\mathrm{VT} / \mathrm{VF}(\mathrm{p}=0.84)$ [16]. The effect of time down during arrest also was described in another trial with a cutoff noted at $10 \mathrm{~min}$ for improved outcomes [32]. Other studies also focused on variables affecting outcomes in TH/TTM-treated patients presenting with OHCA due to nSR [29, 34-36, 39].

\section{Study design}

Four of the five RCTs in this review were small, with cohort sizes ranging from 6 to 16 subjects $[20,45,46,48]$. In the subgroup analysis of the original TTM study [4], a larger cohort was studied but the authors noted that their trial was underpowered [18]. Another issue was that the RCTs were designed with primary endpoints that did not specifically address TH/TTM in nSR. One study was designed to evaluate both the feasibility of a helmet cooling protocol and effects of hypothermia on serum levels of S-100 $\beta$, an astroglial protein that could be a marker, or direct mediator of neuronal injury in OHCA [45]. Another RCT was a pilot study designed to obtain initial data when using different temperature targets for $\mathrm{TH}$ and assess TH effect on outcomes [20]. In another study, the primary endpoint was to assess different levels of hypothermia and their efficacy [18]. The two other RCTs in this study were created to evaluate hemofiltration [46] and rapid in-field cooling in OHCA [25].

With respect to comparing outcomes between PEA arrest and asystole, one trial found that patients presenting with OHCA due to PEA arrest benefitted more from TH than those with asystole [11]. Others also noted possible differences between asystolic and PEA arrest in outcomes in those undergoing TH/TTM $[32,38]$.

The change in the goal temperature for cooling, from TH to TTM, could confound results and analyses of these studies though they were included together in the present study. Differences in cooling protocols, other than target temperature, were noted in some trials. In 1 study there was a difference in the method of hypothermia maintenance based on the time of enrollment with roughly half of patients undergoing more modern techniques. In this same study, there were some patients who did not complete the 24-h period of hypothermia [25]. Variability in the form of maintenance hypothermia was also specifically noted in another non-RCT and could have affected outcomes [23]. In another study, different cooling methods were used in the shockable and non-shockable rhythm groups [45].

The time to outcomes measured in most of these studies was short. Other studies with longer-term follow up demonstrated good outcomes [14, 17, 40].

Though most trials focused on OHCA, some studies included IHCA in their analyses [17, 24, $27,28,37,41]$. Others, which only included abstracts presented at national meetings, may also have included these patients though some did not specifically address this issue in their presentation.

\section{Discussion}

In this focused review, results were outlined from randomized and non-randomized studies of TH/TTM in patients presenting with OHCA due to nSR. As noted in Table 1, there are few high quality studies on this topic. Though it is difficult to make broad conclusions from their findings, these studies do shed light on some factors that may play a role in 
outcomes and could guide clinical decision-making and highlight shortcomings in design that should be kept in mind for future trials.

\section{Outcome variables}

The difficulty with measuring outcomes in OHCA due to nSR is that they are more likely to have many of these features, particularly when compared to VT/VF [7, 12, 16, 18, 24, 25, 45, 47]. Also, each clinical variable may not alter outcomes in a similar fashion in VT/VF and nSR groups [32, 34]. Considering the fundamental differences between these groups, it is not surprising that many found that OHCA due to nSR have worse outcomes when compared to those with SR with TH/TTM. To define the utility of TH/TTM in OHCA due to nSR, studies should compare treatment and control groups within this population.

Some studies specifically focused on factors affecting outcomes in those with nSR undergoing TH/TTM, as noted above. However, many that did this demonstrated baseline differences that would favor survival in the control group, which could have confounded the results and therefore one cannot make significant conclusions from their findings [11, 12, 16, 19, 21, 26, 28, 47]. Nevertheless, evaluating outcome measures in those presenting in nSR, without comparing them to those with VT/ NF, should be replicated in future studies.

\section{Study design}

The highest quality studies available are RCTs but those were ones that evaluated outcomes in $\mathrm{TH} / \mathrm{TTM}$ in OHCA due to nSR and were not specifically designed to address the efficacy of TH/TTM in OHCA in this subgroup. Also, though the RCTs may have been powered for their own primary end points, they were too small to determine outcomes in TH in OHCA due to nSR. These factors have likely contributed to the lack of quality data available.

Analyzing PEA and asystolic arrests together may not be ideal since it has been demonstrated that OHCA due to PEA may portend a better outcome than those due to asystole [7]. This was also demonstrated in the few studies that compared their outcomes [11, 32, 38]. Separate analyses of PEA and asystolic arrests may help elucidate those who would benefit from intervention in these groups.

There were differences in cooling methods and duration of cooling seen across the randomized and non-randomized trials which could have led to inconsistent time-to-target temperature and actual temperature during the testing period. Optimally, cooling protocols could be more consistent in future analyses, given that this inconsistency could confound results.

Differences between nSR and VT/VF with respect to outcomes become less apparent as the length of time to follow up is longer [46]. This is thought to be due to the fact that more time is needed for full recovery after an acute illness and brain injury [6]. Most of these trials used shortterm outcome measures at the time of discharge or a few months afterward but as noted above, those with longer-term follow up showed intervention to be beneficial [14, 17, 40]. Analyzing survival and neurologic function over a longer time period might shed light on the utility of TH/TTM in OHCA due to $\mathrm{nSR}$ as these patients may derive more benefit in the long-term.

Evaluating IHCA with OHCA poses challenges. IHCA patients are more complicated as they often have more varied underlying etiologies, which can include more non-cardiac causes and a higher rate of $n S R$, and they often have more active medical comorbidities which can negatively affect outcomes [24]. A recent article has questioned the efficacy of TH/TTM in IHCA [50]. Therefore, OHCA and IHCA may be evaluated better separately.

\section{Limitations of the study}

This literature review was focused and therefore it is possible that some studies had eluded this search. Also, given that a meta-analysis was not undertaken, there were a lack of high quality studies, variable outcome measures, and confounders limit the utility of this study. Substantive conclusions are also limited by the scope of the studies themselves. The RCTs lack power or an appropriate study design for our purposes. The non-RCTs are limited by inherent shortcomings, including selection bias, their varying outcome measures, confounders, and some by their small subject sizes, as well as others that we have outlined above. Also, given that abstracts included data which were presented at national meetings, we cannot definitively conclude much from them nor can we guarantee they did not include IHCA or pediatric patients.

\section{Conclusions}

In this review and analysis of the most recent data on TH/TTM in OHCA due to nSR, which includes RCTs and non-RCTs, it remained inconclusive as to whether TH/TTM has a role in post-OHCA care in nSR. Most studies are under- 
powered or not primarily designed to make significant conclusions about the efficacy of TH/TTM in OHCA due to nSR. In particular, many compared the efficacy of TH/TTM in nSR to VT/VF, which is problematic due to inherent differences between the two groups. Features that may portend better results within the nSR group itself, which would be useful in defining those who could benefit from $\mathrm{TH} / \mathrm{TTM}$, were analyzed in some studies but were not comprehensive. Analyzing PEA and asystole separately, excluding IHCA, normalizing cooling protocols, and evaluating longer-term outcomes could improve future studies. Based on the results of this review, the benefit of TH/TTM in OHCA due to $\mathrm{nSR}$ is still unclear. An RCT devoted to studying this population is currently enrolling patients [49] and its results could help shed light on the utility of TH/TTM in OHCA due to nSR. Given the possible efficacy of TH/TTM in OHCA due to nSR, the 2015 American Heart Association guidelines are well founded [51] and advocate the use of TTM/ /TH in OHCA due to nSR while proposing that continued study in this field would help to better define those that could benefit from TH/TTM to avoid withholding a possible life-saving intervention while ensuring that expensive resources are not misappropriated.

\section{Conflict of interest: None declared}

\section{References}

1. Terman SW, Hume B, Meurer WJ, et al. Impact of presenting rhythm on short- and long-term neurologic outcome in comatose survivors of cardiac arrest treated with therapeutic hypothermia. Crit Care Med. 2014; 42(10): 2225-2234, doi: 10.1097/ CCM.0000000000000506, indexed in Pubmed: 25014063.

2. Bernard SA, Gray TW, Buist MD, et al. Treatment of comatose survivors of out-of-hospital cardiac arrest with induced hypothermia. N Engl J Med. 2002; 346(8): 557-563, doi: 10.1056/ NEJMoa003289, indexed in Pubmed: 11856794.

3. Hypothermia after Cardiac Arrest Study Group. Mild therapeutic hypothermia to improve the neurologic outcome after cardiac arrest. N Engl J Med. 2002; 346(8): 549-556, doi: 10.1056/NEJMoa012689, indexed in Pubmed: 11856793.

4. Nielsen N, Wetterslev J, Cronberg T, et al. Targeted Temperature Management at $33^{\circ} \mathrm{C}$ versus $36^{\circ} \mathrm{C}$ after Cardiac Arrest. N Engl J Med. 2013; 369(23): 2197-2206, doi: 10.1056/nejmoa1310519.

5. Vaahersalo J, Hiltunen P, Tiainen M, et al. FINNRESUSCI Study Group. Therapeutic hypothermia after out-of-hospital cardiac arrest in Finnish intensive care units: the FINNRESUSCI study. Intensive Care Med. 2013; 39(5): 826-837, doi: 10.1007/s00134013-2868-1, indexed in Pubmed: 23417209.

6. Martinell L, Larsson M, Bång A, et al. Survival in out-of-hospital cardiac arrest before and after use of advanced postresuscitation care: a survey focusing on incidence, patient characteristics, survival, and estimated cerebral function after postresuscitation care. Am J Emerg Med. 2010; 28(5): 543-551, doi: 10.1016/j. ajem.2009.01.042, indexed in Pubmed: 20579548.

7. Andrew E, Nehme Z, Lijovic M, et al. Outcomes following out-of-hospital cardiac arrest with an initial cardiac rhythm of asystole or pulseless electrical activity in Victoria, Australia. Resuscitation. 2014; 85(11): 1633-1639, doi: 10.1016/j.resuscitation.2014.07.015, indexed in Pubmed: 25110246.

8. Fukuda T, Matsubara T, Doi K, et al. Predictors of favorable and poor prognosis in unwitnessed out-of-hospital cardiac arrest with a non-shockable initial rhythm. Int J Cardiol. 2014; 176(3): 910-915, doi: 10.1016/j.ijcard.2014.08.057, indexed in Pubmed: 25168100.

9. Donnino MW, Andersen LW, Berg KM, et al. ILCOR ALS Task Force. Temperature Management After Cardiac Arrest: An Advisory Statement by the Advanced Life Support Task Force of the International Liaison Committee on Resuscitation and the American Heart Association Emergency Cardiovascular Care Committee and the Council on Cardiopulmonary, Critical Care, Perioperative and Resuscitation. Resuscitation. 2016; 98: 97-104, doi: 10.1016/j.resuscitation.2015.09.396, indexed in Pubmed: 26449873.

10. American Academy of Neurology (AAN). SpringerReference, doi: 10.1007/springerreference_183391.

11. Choi SW, Shin SDo, Ro YS, et al. Effect of therapeutic hypothermia on the outcomes after out-of-hospital cardiac arrest according to initial ECG rhythm and witnessed status: A nationwide observational interaction analysis. Resuscitation. 2016; 100: 51-59, doi: 10.1016/j.resuscitation.2015.12.012, indexed in Pubmed: 26774175.

12. Lindner TW, Langørgen J, Sunde K, et al. Factors predicting the use of therapeutic hypothermia and survival in unconscious out-of-hospital cardiac arrest patients admitted to the ICU. Crit Care. 2013; 17(4): R147, doi: 10.1186/cc12826, indexed in Pubmed: 23880105.

13. Sung G, Bosson N, Kaji AH, et al. Therapeutic Hypothermia After Resuscitation From a Non-Shockable Rhythm Improves Outcomes in a Regionalized System of Cardiac Arrest Care. Neurocrit Care. 2016; 24(1): 90-96, doi: 10.1007/s12028-015-0184-z, indexed in Pubmed: 26264064.

14. Testori C, Sterz F, Behringer W, et al. Mild therapeutic hypothermia is associated with favourable outcome in patients after cardiac arrest with non-shockable rhythms. Resuscitation. 2011; 82(9): 1162-1167, doi: 10.1016/j.resuscitation.2011.05.022, indexed in Pubmed: 21705132.

15. Lundbye JB, Rai M, Ramu B, et al. Therapeutic hypothermia is associated with improved neurologic outcome and survival in cardiac arrest survivors of non-shockable rhythms. Resuscitation. 2012; 83(2): 202-207, doi: 10.1016/j.resuscitation.2011.08.005, indexed in Pubmed: 21864480.

16. Soga T, Nagao K, Sawano H, et al. J-PULSE-Hypo Investigators. Neurological benefit of therapeutic hypothermia following return of spontaneous circulation for out-of-hospital non-shockable cardiac arrest. Circ J. 2012; 76(11): 2579-2585, doi: 10.1253/circj. cj-12-0448, indexed in Pubmed: 22813874.

17. Kim YM, Yim HW, Jeong SH, et al. Does therapeutic hypothermia benefit adult cardiac arrest patients presenting with nonshockable initial rhythms?: A systematic review and meta-analysis of randomized and non-randomized studies. Resuscitation. 2012; 83(2): 188-196, doi: 10.1016/j.resuscitation.2011.07.031, indexed in Pubmed: 21835145.

18. Frydland M, Kjaergaard J, Erlinge D, et al. Target temperature management of $33^{\circ} \mathrm{C}$ and $36^{\circ} \mathrm{C}$ in patients with out-of-hospital 
cardiac arrest with initial non-shockable rhythm — a TTM substudy. Resuscitation. 2015; 89: 142-148, doi: 10.1016/j.resuscitation.2014.12.033, indexed in Pubmed: 25629544.

19. Kim MJ, Shin SDo, McClellan WM, et al. Neurological prognostication by gender in out-of-hospital cardiac arrest patients receiving hypothermia treatment. Resuscitation. 2014; 85(12): 1732-1738, doi: 10.1016/j.resuscitation.2014.09.018, indexed in Pubmed: 25281187.

20. Lopez-de-Sa E, Rey JR, Armada E, et al. Hypothermia in Comatose Survivors From Out-of-Hospital Cardiac Arrest: Pilot Trial Comparing 2 Levels of Target Temperature. Circulation. 2012; 126(24): 2826-2833, doi: 10.1161/circulationaha.112.136408.

21. Dumas F, Grimaldi D, Zuber B, et al. Is hypothermia after cardiac arrest effective in both shockable and nonshockable patients?: insights from a large registry. Circulation. 2011; 123(8): 877-886, doi: 10.1161/CIRCULATIONAHA.110.987347, indexed in Pubmed: 21321156.

22. Storm C, Nee J, Roser M, et al. Mild hypothermia treatment in patients resuscitated from non-shockable cardiac arrest. Emerg Med J. 2012; 29(2): 100-103, doi: 10.1136/emj.2010.105171, indexed in Pubmed: 21362725.

23. Wee JH, You YHo, Lim H, et al. Korean Hypothermia Network Investigators. Outcomes of asphyxial cardiac arrest patients who were treated with therapeutic hypothermia: a multicentre retrospective cohort study. Resuscitation. 2015; 89: 81-85, doi: 10.1016/j.resuscitation.2014.11.001, indexed in Pubmed: 25447037.

24. Hoffmann S, Ersgaard R, Kristensen ML, et al. Therapeutic hypothermia after cardiac arrest in a real-life setting. Dan Med J. 2016; 63(2), doi: 10.1007/978-1-4471-2951-6, indexed in Pubmed: 26836799.

25. Uribarri A, Bueno H, Pérez-Castellanos A, et al. Impact of time to cooling initiation and time to target temperature in patients treated with hypothermia after cardiac arrest. Eur Heart J Acute Cardiovasc Care. 2015; 4(4): 365-372, doi: 10.1177/2048872614557241, indexed in Pubmed: 25344490.

26. Kocjancic ST, Jazbec A, Noc M. Impact of intensified postresuscitation treatment on outcome of comatose survivors of out-of-hospital cardiac arrest according to initial rhythm. Resuscitation. 2014; 85(10): 1364-1369, doi: 10.1016/j.resuscitation.2014.06.028, indexed in Pubmed: 25010782.

27. Ganga HV, Kallur KR, Patel NB, et al. The impact of severe acidemia on neurologic outcome of cardiac arrest survivors undergoing therapeutic hypothermia. Resuscitation. 2013; 84(12): 1723-1727, doi: 10.1016/j.resuscitation.2013.07.006, indexed in Pubmed: 23916553.

28. Gebhardt K, Guyette FX, Doshi AA, et al. Post Cardiac Arrest Service. Prevalence and effect of fever on outcome following resuscitation from cardiac arrest. Resuscitation. 2013; 84(8): 1062-1067, doi: 10.1016/j.resuscitation.2013.03.038, indexed in Pubmed: 23619740.

29. Schenone AL, Cohen A, Patarroyo G, et al. Therapeutic hypothermia after cardiac arrest: A systematic review/meta-analysis exploring the impact of expanded criteria and targeted temperature. Resuscitation. 2016; 108: 102-110, doi: 10.1016/j.resuscitation.2016.07.238, indexed in Pubmed: 27521472.

30. Modisett KL, Walsh SJ, Heffner AC, et al. Outcomes in Cardiac Arrest Patients due to Toxic Exposure Treated with Therapeutic Hypothermia. J Med Toxicol. 2016; 12(3): 263-269, doi: 10.1007/ s13181-016-0536-x, indexed in Pubmed: 26856349.
31. Whittaker A, Lehal M, Calver AL, et al. Predictors of inhospital mortality following out-of-hospital cardiac arrest: Insights from a single-centre consecutive case series. Postgrad Med J. 2016; 92(1087): 250-254, doi: 10.1136/postgradmedj-2015-133575, indexed in Pubmed: 26739845.

32. Kim WY, Ahn S, Hong JS, et al. The impact of downtime on neurologic intact survival in patients with targeted temperature management after out-of-hospital cardiac arrest: National multicenter cohort study. Resuscitation. 2016; 105: 203-208, doi: 10.1016/j.resuscitation.2016.03.020, indexed in Pubmed: 27060537.

33. Afzal A, Alsahhar J, Mora A. Therapeutic Hypothermia: Implementation and Disposition Outcomes at a Tertiary Care Institution. Chest. 2014; 146(4), doi: 10.1378/chest.1990861.

34. Thomsen JH, Soeholm H, Hassager C, et al. Comorbidity as a risk factor in survivors of non-shockable out-of-hospital cardiac arrest treated with hypothermia. Eur Heart J. 2014;35: 315-315.

35. Lazzeri C, Gensini GF, Sori A, et al. Dynamic behaviour of lactate values during mild hypothermia in patients with cardiac arrest. Eur Heart J Acute Cardiovasc Care. 2014; 3(2): 176-182, doi: 10.1177/2048872613514014, indexed in Pubmed: 24337917.

36. Kim WY, Giberson TA, Uber A, et al. Neurologic outcome in comatose patients resuscitated from out-of-hospital cardiac arrest with prolonged downtime and treated with therapeutic hypothermia. Resuscitation. 2014; 85(8): 1042-1046, doi: 10.1016/j. resuscitation.2014.04.005, indexed in Pubmed: 24746783.

37. Dell'anna AM, Viotti JB, Beumier M, et al. C-reactive protein levels after cardiac arrest in patients treated with therapeutic hypothermia. Resuscitation. 2014;85(7):932-8.

38. Coute RA, Mader TJ, Nathanson BH, Mislaszek R, Ciapp M, McNally B. Therapeutic hypothermia after out-of-hospital cardiac arrest due to initial non-shockable rhythms. Acad Emerg Med. 2011;18(5):Suppl 1 (S212-).

39. Investigation and treatment of pulmonary embolism as a potential etiology may be important to improve post-resuscitation prognosis in non-shockable out-of-hospital cardiopulmonary arrest: report on an analysis of the SOS-KANTO 2012 study. Acute Medicine \& Surgery. 2016; 3(3): 250-259, doi: 10.1002/ ams2.183.

40. Fontanals J, Magaldi M, Fontanals M, et al. Target temperature management of $33^{\circ} \mathrm{C}$ in patients with cardiac arrest due to nonshockable rhythm. Resuscitation. 2015; 96: 38, doi: 10.1016/j. resuscitation.2015.09.088.

41. Katz AZ, Grossestreuer AV, Gaieski DF, et al. Outcomes of patients resuscitated from cardiac arrest in the setting of drug overdose. Resuscitation. 2015; 94: 23-27, doi: 10.1016/j.resuscitation.2015.06.015, indexed in Pubmed: 26126505.

42. Lee EJ, Shin SD, Song KJ, Ro YS, Hong WP. Outcome of Mild therapeutic Hypothermia in Out-of-Hospital Cardiac Arrest: A Nationwide Retrospective Analysis. Circulation. 2013;128(22 Supplement):A229.

43. Nair SU, Morris D, Kallur KR, et al. Relationship of Downtime and Cardiopulmonary Resuscitation Time to Neurologic Outcome in Patients with Nonshockable Rhythm Undergoing Therapeutic Hypothermia. Circulation. 2011; 124(Suppl 21): A116.

44. Pfeifer R, Jung C, Purle S, et al. Survival does not improve when therapeutic hypothermia is added to post-cardiac arrest care. Resuscitation. 2011; 82(9): 1168-1173, doi: 10.1016/j.resuscitation.2011.05.024, indexed in Pubmed: 21715080. 
45. Hachimi-Idrissi S, Zizi M, Nguyen DN, et al. The evolution of serum astroglial S-100 beta protein in patients with cardiac arrest treated with mild hypothermia. Resuscitation. 2005; 64(2): 187-192, doi: 10.1016/j.resuscitation.2004.08.008, indexed in Pubmed: 15680528.

46. Laurent I, Adrie C, Vinsonneau C, et al. High-volume hemofiltration after out-of-hospital cardiac arrest: a randomized study. J Am Coll Cardiol. 2005; 46(3): 432-437, doi: 10.1016/j. jacc.2005.04.039, indexed in Pubmed: 16053954.

47. Perman S, Grossestreuer AV, Wiebe DJ, Carr BG, Abella BS, Gaieski DF. The Utility of Therapeutic Hypothermia for PostCardiac Arrest Syndrome Patients With an Initial Non-Shockable Rhythm. Circulation. 2015;132:2146-51.

48. Kim F, Olsufka M, Longstreth WT, et al. Pilot randomized clinical trial of prehospital induction of mild hypothermia in out-ofhospital cardiac arrest patients with a rapid infusion of 4 degrees C normal saline. Circulation. 2007; 115(24): 3064-3070, doi: 10.1161/CIRCULATIONAHA.106.655480, indexed in Pubmed: 17548731 .

49. Lascarrou JB, Meziani F, Le Gouge A, et al. Clinical Research in Intensive Care and Sepsis (CRICS) Group and HYPERION Study Group. Therapeutic hypothermia after nonshockable cardiac arrest: the HYPERION multicenter, randomized, controlled, assessor-blinded, superiority trial. Scand J Trauma Resusc Emerg Med. 2015; 23: 26, doi: 10.1186/s13049-015-0103-5, indexed in Pubmed: 25882712.

50. Arrich J, Holzer M, Herkner H, Mullner M. Hypothermia for neuroprotection in adults after cardiopulmonary rescuscitation. Cochrane Database of Systematic Reviews 2009, Issue 4.

51. Callaway CW, Donnino MW, Fink EL, et al. Part 8: post-cardiac arrest care: 2015 American Heart Association guidelines update for cardiopulmonary resuscitation and emergency cardiovascular care. Circulation. 2015; 132(18) (suppl 2): S465-S482. 